\title{
Psicanálise e família: percalços do édipo e seus destinos trágicos ${ }^{1}$
}

\author{
Maria do Carmo Cintra de Almeida Prado ${ }^{2}$
}

As condições para a saúde psíquica estão relacionadas às capacidades de amar em termos objetais, de ter prazer e de suportar o sentimento de luto, sendo esta última condição que torna possível as duas primeiras. Há aqueles que não se veem com meios de fazer face a nenhum luto, à dor psíquica relativa a decepções, à perda de amores e ilusões, e procuram evita-lo a qualquer custo, mas é então o seu entorno que ficará com o encargo. Será a travessia do luto originário que promoverá uma mudança psíquica básica através da abertura para o outro e da descoberta da interioridade, travessia esta tão importante quanto a transformação operada no psiquismo pela do édipo (Racamier, 1992). Delas decorrem garantias metassociais e metapsíquicas, funções de enquadramento regradas, crenças compartilhadas e representações comuns, circunstâncias que fundamentam a ordem simbólica, com a lei que se impõe a todos e organiza o conjunto, sem as quais estar-se-á às voltas com o arbitrário e a anomia.

Em família tais efeitos estão operando e justamente atuantes na constituição de cada sujeito, necessariamente a partir de um outro, ele próprio fruto de uma história cujas raízes se encontram em seu grupo de pertença, familiar e social, do qual é porta-voz. Ao grupo específico que é cada família corresponde uma intersubjetividade vincular exclusiva composta de distintos sujeitos do Incosnciente, que a compõem e dela decorrem (Kaës,

\footnotetext{
${ }^{1}$ Este trabalho foi apresentado em "Trabalhos livres" no I Simpósio Bienal "O mesmo, o outro: Psicanálise em movimento” da Sociedade Brasileira de Psicanálise de São Paulo. Forma reduzida de artigo proposto em coletânea (no prelo).

${ }^{2}$ Doutora em Psicologia Clínica (PUC-Rio)

Psicóloga do Instituto de Psicologia da UERJ

Coordenadora dos Setores de Psicodiagnóstico Diferencial (de 1982 a 2017) e de Terapia de Família (de 1990 a 2017) da Unidade Docente-Assistencial de Psiquiatria do Hospital Universitário Pedro Ernesto / UERJ

Membro Efetivo e Docente da Sociedade Psicanalítica do Rio de Janeiro (SPRJ)

Membro Efetivo da International Psychoanalytical Association (IPA)

Membro Associado da Association Internationale de Psychanalyse du Couple et de la Famille (AIPCF)

Membro Associado do Instituto Brasileiro de Avaliação Psicológica (IBAP)
} 
2017). Em se tratando de psicanálise de família, existe um elo entre os efeitos da intersubjetividade e as formações e processos inconscientes que ela constitui e que nela estão implicados.

A família com funcionamento prevalentemente narcísico se apresenta intolerante ao luto originário e carente de interdição, o que se evidencia na relação com um de seus membros em particular, referido como figurante predestinado (Racamier, 1989). Preso a suas veleidades infantis, ele se vê enredado em relação perversa narcísica pautada pelo ant'édipo mal temperado, na qual cada genitor tem parte ativa numa psicodinâmica caracterizada pelo incestual (Racamier, 1989). Ao apresentar a noção de configuração edípica Faimberg (2001) acentua uma extensão maior, na qual se associa certo funcionamento narcisista ao contexto edípico, que envolve a identificação com a forma como os pais possam ter feito face a um conflito narcísico.

Apresentamos uma família composta por casal beirando os 60 anos, com instrução superior, Helena e João, e três filhos: Lúcia, profissional, morava com o marido e duas filhas; Inês, policial, preparava-se para casar, e Joãozinho, que portava o nome do pai, 30 anos, nível superior, sem autonomia financeira, nunca trabalhara, vivia isolado, sem amigos e sem ter tido envolvimento afetivo. Um episódio de agressividade para com o pai implicou em internação psiquiátrica. Haja vista evidentes dificuldades nas relações familiares, deu-se encaminhamento para terapia de família, a qual compareceu apenas o casal parental. As filhas não se viam implicadas e o filho recusou-se a participar.

Foi relatado que Joãozinho permanecia o dia todo em casa atrás da mãe demandando atenção. Costumava chama-la a seu quarto, mas muitas vezes a agredia. Segundo Helena, quando "perdeu a vergonha" (sic), passou a dar-lhe beliscões na frente dos outros, inclusive do pai. Este justificou não se interpor entre mãe e filho porque, ao fazê-lo, "ela passaria mal" (sic), além de afirmar já tê-lo enfrentado fisicamente e ter sido agredido por ele, que o chamava de zero à esquerda. Assinalou sentir ciúmes da mulher e ter sempre sentido "como se estivesse atrapalhando alguma coisa entre eles" (sic).

Nesse acolhimento à família, uma situação se esboçava: Helena dizer que o filho perdera a vergonha sugere que ele passara a fazer algo que deveria ser mantido em segredo entre eles, longe de olhos alheios, inclusive - ou sobretudo? -, os do pai. João, por outro lado, 
justifica sua falta de intervenção para que Helena não passe mal - então é ela quem detém o poder -, mas assinala a seguir que, diante do filho, ele não tem força, nem moral, nem física. Constata-se que o interdito do tocar não está operante entre mãe e filho, e sexualidade e agressividade, misturadas, expressam a violência pulsional. A conotação sexual se acentua através da aliança "secreta" entre mãe e filho, sugestiva de outra transgressão, a edípica, pelas costas do marido-pai, mantido à parte não apenas por eles, mas também por suas próprias razões: João se via e era visto como sem força.

Todo interdito é bilateral e deve se aplicar ao emissor das interdições e a seu destinatário. Para que exerça seu efeito de reestruturação do funcionamento psíquico, o interdito do tocar, assim como o edípico, requer que seja respeitado pelos pais (Anzieu, 1985). Quando isto não ocorre, dão-se faltas graves e repetitivas das quais decorre um traumatismo cumulativo, com importantes consequências psicopatológicas. O interdito primário do tocar impõe uma existência separada ao ser em vias de se individuar e envolve experiências que terão daí por diante que ser fantasiadas. A interdição é significada à criança pela mãe sob a forma ativa de uma tomada de distância física e quando ela falha nesse sentido, é relevante que alguém do meio possa intervir como porta-voz do interdito para que o filho cresça e tenha espaço e tempo para viver por si mesmo. O interdito secundário do tocar se aplica à pulsão de dominação: não se pode tocar em tudo, tomar posse de tudo, ser mestre de tudo. O sentido explícito implicado é que não apenas não se pode pegar, mas tem-se que aceitar o risco da recusa ou do adiamento. A transgressão do interdito do tocar se apresenta como terreno fértil para a perversão narcísica, cuja origem se encontra no universo megalomaníaco infantil e primitivo, na esteira da sedução narcísica perpetuada (Racamier, 1987).

Buscando-se averiguar sobre as agressões físicas do filho para com a mãe, descobrimos que estas se davam há muito tempo, desde que Joãozinho contava 15 anos, quando começou a dar-lhe "soquinhos" ao estarem a sós. Com o tempo, passou a agredi-la com beliscões, socos, chutes e puxões de cabelo, numa violência sempre crescente, causandolhe hematomas, escondidos por ela. Seu silêncio se justificava por "querer que tudo fosse como era antes, que a família não se separasse" (sic). No entender dela, a descoberta do que se passava entre ela e o filho "estragara tudo" (sic), pois suas filhas se posicionaram de forma bastante radical diante da situação, vista por elas como inaceitável: Lúcia deixou 
de frequentar a casa dos pais, privando-os do convívio com as netas, e Inês afastou-se da convivência com o irmão.

Esboçam-se aqui dificuldades inerentes ao tempo e às mudanças que forçosamente implica, inclusive relativas à separação, intrínseca ao próprio crescimento. Ser como era antes, mas "antes" do que? Um tempo mítico, eterno, sem evolução, de permanência contínua, portanto sem separação. Joãozinho nada tem na vida a não ser a mãe, apenas ela deseja, exclusiva para si, e nada mais lhe importa. Por sua vez, ela o privilegia em detrimento do marido e, assim, mãe e filho permanecem presos numa sedução narcísica interminável, que corresponde à fascinação mútua, originalmente entre o bebê e sua mãe, com vistas a um ser simbiótico único, todo-poderoso, ao abrigo das vicissitudes pulsionais e da ambivalência, das separações e dos lutos, de forma que a rivalidade edípica fique fora do circuito (Racamier, 1987).

O incesto é o contrário do édipo, não se limita à forma física e tem equivalentes, que correspondem ao incestual (Racamier, 1992). Com vistas à imunidade conflitual, a sedução narcísica se perpetua e desemboca no ant'édipo mal temperado, que abre as portas para a perversão narcísica e o incesto ou seus equivalentes. Assim, no complexo de Édipo parricídio e incesto podem ser considerados, ainda que não somente, como uma luta narcisista que se origina da ilusão de existir apenas um espaço psíquico, no qual nunca haverá mais do que um único objeto erótico (Faimberg, 2001). Outro complicador se junta a essa história: a perda da primogênita, com um ano de idade, devido à catapora insuficientemente tratada. No que diz respeito à compreensão do trabalho de luto e dos lutos patológicos, novos esclarecimentos são alcançados ao se opor o registro incestuoso ao edípico. As relações narcísicas incestuosas ou incestuais, com seus profusos desdobramentos paradoxais, lutam tragicamente contra as angústias de separação, vivenciada como catastrófica.

O édipo diferencia os seres e as gerações, as realidades interna e externa, o interior da família e o exterior dela, mas é preciso acrescentar, conforme tão bem assinala Caillot (1995), os mortos dos vivos, o animado do inanimado. Seu organizador é o duplo interdito do incesto, o duplo interdito do tocar. As confusões paradoxais morto-vivo pertencem bem ao registro incestuoso: aliás, assinala o autor, talvez possamos falar de vivo-não-vivo - ou de morto-não-morto, diríamos. Nessas condições, o filho de substituição, aquele que 
ocupa o lugar de um filho morto, cujo nome muitas vezes carrega, será o "tapa-luto”, o "para-luto". No registro incestual aqui abordado nos deparamos com uma mãe-não mãe, a mãe-amante do filho pelas costas do pai-marido-zero-à-esquerda, com o filho-amante que a compreende e acolhe face ao luto não elaborado da filha e que passa a funcionar como "tapa-luto". Destaca-se o estabelecimento de um funcionamento psíquico paradoxal, permanecendo a morta investida desse mesmo modo paradoxal.

Lutos congelados "protegem" da depressão profunda, mas provocam um desperdício de vida por todas as impossibilidades que acarretam e pela estreiteza de perspectivas que geram, com o tempo paralisado em termos psíquicos, já que ele não para nunca. Nessas circunstâncias, um outro interdito é transgredido, e se matar não é possível, existem outros meios... Sem trabalho, sem estudo, sem relações sociais, sem vida amorosa, sem nenhuma perspectiva, sem nenhum recurso sublimatório, a existência de Joãozinho é a de um vivo-morto. Helena demonstra não desejar abrir mão da intimidade com ele pelas gratificações narcísicas que lhe proporcionam, mas sobretudo como uma garantia de evitar a depressão e o que seja temido como um desmoronamento psíquico. João, inseguro, preterido, sem valor, conforma-se à situação e paradoxalmente a sustenta ativamente com sua passividade e impotência.

Materiais intrapsíquicos insuficientemente elaborados se transformam em venenos psíquicos expulsados no meio (Racamier, 1992). Recusa, clivagem e denegação correspondem a defesas poderosas para impedir o pensar e, em família, seus membros se apresentam como complemento operatório das defesas em jogo. A perversão narcísica, portanto, está longe de ser um assunto intrapsíquico, já que é altamente interativo. Sem pactos de renúncia, não há condição de ser.

\section{Referências}

Anzieu, D. (1985) Le Moi-peau. Paris : Dunod.

Faimberg, H, (2001) Gerações: mal-entendido e verdades históricas. Porto Alegre: Criação Humana.

Kaës, R. (2017) Les théories psychanalytiques du groupe. Paris : Presses Universitaires de France/Humensis. 
Racamier, P.-C. (1987) De la perversion narcissique.Gruppo 3. Perversité das le famille. Paris : APSYGEE, 11-23.

Racamier, P.-C. (1989) Antoedipe et ses destins. Paris : APSYGEE.

Racamier, P.-C. (1992) Le génie des origines. Paris : Payot. 